\title{
Riziko a jeho pojetí: vědecké a umělecké
}

\author{
Vážení čtenáři,
}

pojem riziko patří k nejčastěji používaným pojmům v ekonomické vědě. Původ tohoto slova je nutno hledat ve staré řečtině, kde se slovem „riza“ (psáno „pı $\alpha ”)$ údajně označoval „,kořen“, tj. jakási překážka na cestě, o níž by mohl poutník na své cestě zakopnout. V podobném významu se tento termín objevil později v latině, kde představoval „útes“, o něhož se mohou rozbít lodě. Následně se začalo toto slovo $\mathrm{v}$ podobné podobě vyskytovat i v dalších jazycích ve smyslu nebezpečí, jemuž musí čelit obchodníci při dopravě po moři. Do angličtiny se slovo „risk“ dostalo patrně z kontinentální Evropy až v 17. století. ${ }^{1}$ Odtud už jsme blízko k chápání rizika jako jakéhokoliv nebezpečí, at' už v práci, v politice, $v$ obchodu, ve financích, $v$ životě nebo třeba i v lásce.

Z hlediska teoretické diskuse k pojmu riziko lze vysledovat pět následujících otázek, které jsou stále předmětem učené rozpravy. Je riziko totéž co nejistota? Je riziko pravděpodobnost? Je riziko měřitelné a nejistota neměřitelná? Představuje riziko pouze záporné odchylky od očekávaného výsledku nebo i kladné? Existuje riziko bez nejistoty?

Předem je nutné uvést, že ačkoliv mohou být přístupy $\mathrm{k}$ vymezení pojmu riziko různé, přesto nakonec mohou mít všichni autoři pravdu. Z hlediska věcné logiky platí každá definice pouze za předpokladu existence určitých podmínek. A v tomto smyslu může každý autor pracovat s odlišnými podmínkami, at' již výslovně zmíněnými či nikoliv. Proto nelze jednoznačně říci, která odpověd' na výše uvedené otázky bude jediná správná, nebot' každý autor má právo si zvolit svoji vlastní cestu. Shrneme-li dosavadní př́stupy, potom pod pojmem riziko se zpravidla rozumí nebezpečí vzniku události, která může mít podobu napřr. zakopnutí o vyčnívající kořen, ztroskotání lodi na útesu, anebo finanční ztráty z neuskutečněného obchodu, poškození zboží, nezaplacení za dodávku, apod. Jinými slovy řečeno, riziko představuje „,nebezpečí, že se skutečné výsledky budou lišit od výsledků očekávaných “2.

Pojem riziko není však pojmem, na jehož vysvětlování by měla věda výlučné právo. Různé př́stupy k pochopení jeho podstaty lze nalézt i ve světě umění. Riziko se stalo námětem mnoha písní, básní, ale i výtvarných, literárních či dramatických děl.

Pokud se podíváme na texty písní s názvem „Riziko“, nejblíže k vědecké definici se nachází zpěvák country music, Paul Brandt, který přirovnává riziko k situaci, kdy stojí na hraně útesu, čímž se vlastně dostává k původnímu významu tohoto slova ve staré řečtině. ${ }^{3}$ Skupina Elán ze Slovenska shledává riziko v uměleckém světě v nejčastěji analyzovaném konfliktu, ve vztahu soužití muže a ženy. Pro zamilovaného muže zde nebezpečí budoucího nepříznivého vývoje událostí vyplývá z nedostatečné znalosti minulého stavu sledované osoby, a z toho plynoucího možného nesprávného vyvození závěrů. ${ }^{4} \mathrm{~V}$ podobném duchu se objevuje riziko i v českých písních. Písničkář a textař, Jaromír Nohavica, však zavádí navíc

1 Luhmann, N.: Modern Society Shocked by Its Risk. [on-line], Hong Kong, University of Hong Kong, 1996, [cit. 1. 8. 2011], <http://hub.hku.hk/handle/10722/42552/1/17.pdf>.

Marek, P.: Studíjní průvodce financemi podniku. Praha, Ekopress, 2009, s. 75.

I'd rather stand on the edge of a cliff, and hang my toes over a bit. (Brandt, P.: Risk)

Našiel som si super kost', má pochybnú minulost'. (Elán: Riziko) 
nový ukazatel pro účely měření rizika, tzv. koeficient rizika, přesný způsob jeho konstrukce však dosud nerozpracoval. ${ }^{5}$ Básní věnovaných riziku není př́liš mnoho. Za jeden z nejzajímavějších počinů lze označit velmi často citovanou báseň „,Risk“ od W. A. Warda. ${ }^{6}$ Ve svém textu poukazuje na to, že každá lidská činnost může vést $\mathrm{k}$ neúspěchu, a člověk se přitom vystavuje přinejmenším nebezpečí posměchu ze strany ostatních lidí. Ale ten, kdo nic nedělá, kdo se o nic nepokouší, ten vlastně neexistuje. Pouze tedy ten, kdo riskuje, se stává skutečně svobodným. ${ }^{7}$ Ve výtvarném umění bývá riziko zobrazováno zpravidla v podobě záporné odchylky od očekávaného výsledku, např̀. vobraze Estetikum rizika rumunské malíŕky M. S. Oprea se objevují postavy plné hrůzy z budoucnosti. ${ }^{8}$ Kanadský malíŕ P. J. Mills si představuje pod rizikem ekologické škody, jež mohou ve svém důsledku vést až k zániku planety Země, což vyjadřuje postupně se rozmazávající mapou světa. ${ }^{9}$

Na závěr mého úvodníku mi dovolte, abych se i já pokusil svými vlastními verši přispět $\mathrm{k}$ diskusi ohledně umělecké podstaty pojmu riziko.

\author{
Co je to riziko? \\ Je to kořen, je to skála? \\ Lod'se na útesech potopila. \\ Je to pravda, nebo pouhý sen? \\ Co prinese nám př́ǐstí den? \\ Analytik $z$ kotle čísel věští. \\ Jednou je jeho odhad horší, \\ jednou lepší. \\ Co je to riziko? \\ Pouhé nebezpečí, muška na obloze, \\ co prinese jednou smi̊lu, \\ a jednou štěstí.
}

\author{
prof. Ing. Petr Marek, CSc. \\ předseda redakční rady Českého finančního a účetního časopisu \\ a řešitel výzkumného záměru \\ Rozvoj účetní a finanční teorie \\ a její aplikace v praxi z interdisciplinárního hlediska
}

\footnotetext{
5 Proto dř́v, než jdeš do akce, sečti výšku a, hmotu b a tlak c, násob koeficientem rizika, poděl váhou politika. (Nohavica, J.: Tanec mezi vejci).

6 Nicméně o autorství této básně se vedou spory. Vedle Williama Arthura Warda (1921-1994) bývá tato báseň přisuzována rovněž Felice Leonardovi Buscagliovi (1924-1988), nicméně nejčastěji je na internetu uváděno, že autor básně není známý.

7 To laugh is to risk appearing a fool, to weep is to risk appearing sentimental, to reach out to another is to risk involvement, to expose feelings is to risk exposing your true self, to place your ideas and dreams before a crowd is to risk their loss, to love is to risk not being loved in return, to hope is to risk despair, to try is to risk to failure. But risks must be taken because the greatest hazard in life is to risk nothing. The person who risks nothing, does nothing, has nothing is nothing. He may avoid suffering and sorrow, but he cannot learn, feel, change, grow or live. Chained by his servitude he is a slave who has forfeited all freedom. Only a person who risks is free. (Ward, W.A.: Risk)

8 Obraz Aesthetics of Risk od Maia Stefana Oprea. [on-line], High Point, FineArtAmerica, c2009, [cit. 1. 8. 2011], <http://fineartamerica.com/featured/the-aesthetics-of-risk-maia-oprea.html>.

9 Obraz Risk od Patricka Johna Millse [on-line], Ottawa, Patrick John Mills Contemporary Fine Art Gallery, c2009, [cit. 1. 8. 2011], <http://www.patrickjohnmills.com/MapSeries.htm>.
} 